\title{
An Empirical Analysis of the Relationship between e-government and Corruption
}

Jamshed J. Mistry. Suffolk University. USA.

Abu Jalal. Suffolk University. USA. jmistry@ suffolk.edu

\begin{abstract}
The purpose of this paper is to examine the relationship between e-government and corruption in developed and developing countries. Specifically, we investigate two issues - (1) the impact of the use of e-government on corruption in countries around the world and (2) whether the impact of e-government on corruption will be higher in developed or developing countries. In order to examine these relationships we develop and test empirical models that investigate these relationships. The results suggest that as the use of ICT related e-government increases corruption decreases. We also find that the impact of e-government is higher in developing countries than in developed countries for the seven-year period between 2003 and 2010.
\end{abstract}

Keywords: ICT, digital divide, e-government, e-governance, corruption.

\section{INTRODUCTION}

Technological advancements have been credited for playing a significant role in the globalization of trade, communication, and life styles. Vasarhelyi and Alles (2008) suggest a new business model based on technological advancements. They state that: "Businesses are taking the lead to adapt and to also accelerate the

The authors would like to thank Krishnagopal Menon and two anonymous reviewers for their invaluable comments on earlier drafts of the paper. 
development of the "now" economy, through the widespread adoption of integrated company software such as enterprise resource planning systems (ERP), modern communication technologies that ensure that workers are on the job $24 / 7 / 365$, and monitoring systems that give a greater range of managers the ability to track and control key business processes."

Thus, modern communication technologies or information and communications technologies (ICT) have been credited with not only improving efficiency or productivity in the business world but also with improving the standard of living for global citizens. This has been particularly apparent in the industrialized world, although the recent economic crisis has resulted in a slowdown of (ICT) spending in Europe and USA (Rojko et al., 2011).

However, the role of ICT in serving as a catalyst to enhance economic development and the quality of life in developed and developing countries continues to be debated in the research literature ( $\mathrm{Lu}, 2001$; Mansell, 2001; Mistry, 2005; Brynjolfsson and Saunders, 2010). Recently, countries around the world have utilized ICT in an attempt to efficiently provide information and governmental services to the population. The use of ICT to provide information to citizens and to connect citizens and government has been called e-governance or e-government in the research literature. Some researchers have suggested that egovernment is only a subset of e-governance (albeit a major one) while others have suggested that e-government and e-governance cannot be defined the same way and must be viewed differently (Palvia and Sharma, 2007). These authors also contend that e-government is a generic term that refers to the delivery of government information and services via the internet, while e-governance is a broader idea that refers to the use of ICT by government and private organizations to execute the functions of managing effectively (Bannister and Walsh, 2002; Finger and Pecoud, 2003). Since our focus is on the use of ICT in government and the delivery of information to provide services to civilians in local or national government and not on private organizations that may use ICT to manage effectively we will utilize the generic term e-government.

Research in the field of e-government has broadly focused on five themes: 1) Technological innovation and modernization - the use of ICT to provide public services more efficiently; 2) e-government project evaluation and policy analysis - the evaluation of public programs related to e-government initiatives; 3) e- 
Participation and digital democracy - changes in the relationship between governments and citizens due to the use of e-governance; 4) e-Services - the transformation of the delivery of public goods and services as a result of ICT; and 5) accountability, transparency and dissemination of information - the use of the internet to disseminate information and governmental services that could result in greater transparency (Rodriguez et al., 2010). Although three of these themes appear to focus on public services, the same themes can also be the focus of egovernment as e-government is concerned with providing similar services to citizens. Thus, prior research suggests that ICT can be utilized to provide public services more efficiently and disseminate information to citizens. In addition, prior research has also suggested that the main rationale for the use of egovernment and e-governance is that it can reduce costs and delays in processing and delivering services, expand citizen's access to public sector information, increase transparency and public accountability, and weaken authoritarian tendencies (Haque, 2002).

Corruption has been cited as one of the most prevalent and persistent challenges in enhancing economic growth and improving the quality of life of citizens across the globe. The World Bank's 2011 guide identifies corruption as "one of the single greatest obstacles to economic development and social development". It goes on to state that "through bribery, fraud and the misappropriation of economic privileges, corruption diverts resources away from those who need them most" . Focusing on East Asia in particular, two World Bank publications have offered frameworks, strategies, and tools to challenge corruption in both the private (Arvis and Berenbeim, 2004) and the public sectors (Bhargava and Bolongaita, 2004). In countries large or small, market driven or otherwise, governments have fallen and prominent politicians like presidents and prime ministers have been removed after being accused of corruption (Backus, 2001). Current research documenting how corruption hinders economic development provides a compelling argument that efforts to challenge corruption are especially important in the developing world (Ahmad and Brookins, 2007; Mistry, 2012).

In this paper, we focus specifically on the potential role of e-government in mitigating corruption. We test the relationship between ICT driven e-government and corruption by developing and testing empirical models that examine how 
changes in the use of e-government in various countries are linked to changes in their levels of corruption. Next, we examine whether developed or developing countries benefit most from greater use of ICT or e-government. Finally, to further test the strength of the relation between e-government and corruption we estimate a Probit model that considers dependent and independent variables from two different time periods.

The rest of the paper is organized as follows. The first section defines corruption and its role as a barrier to economic development. In the second section, we discuss the role of e-government in dismantling corruption and argue that e-government techniques can be utilized by both developed and developing countries to target corruption. The third section presents the data and methodology utilized to conduct our empirical analyses. The empirical analysis is presented in the fourth section while the results are presented in the fifth section. Finally, the sixth section discusses the results and the contributions of the study and the limitations.

\section{CORRUPTION - AN OBSTACLE TO ECONOMIC DEVELOPMENT}

Some researchers have defined corruption as an act in which the power of public office is used for personal gain in a manner that contravenes the rules of the game (Jain, 2001; Tanzi, 1998) while others have defined it as the abuse of public power for private benefit (Rose-Ackerman, 1999). For example, as Tanzi (1998) opines, although the definition of corruption suggests that it is the abuse of public power for private benefit, it cannot be concluded that corruption does not exist in the private sector. Tanzi (1998) goes on to state that it exists in large private enterprises, especially in procurement and hiring issues. In the public sector, it can raise public expenditure and lower the amount of tax received, thereby increasing fiscal deficits and creating macro-economic instability (Mauro, 1997; Bhargava and Bolongaita, 2004). Scholarship on corruption in the past decade (Aides and Di Tella, 1999; Aidt, 2003; Elliot, 1997; Jain, 2001; Mauro, 1997; Svensson, 2005; Tanzi, 1998) has indicated that corruption discourages investment, limits economic growth, alters the composition of government spending, usually undercuts a nation's mission of reducing poverty and hinders improvement in the quality of life for the rural and poor segments of developing countries (Bhargava and Bolongaita, 2004). Using indices of government corruption, along with country level economic data, Mauro (1997) documents that the amount of 
corruption is negatively linked to the level of investment and economic growth. The analysis further indicates that when the corruption index improved by one standard deviation, the country's investment rate increased by more than 4 percentage points and the annual growth rate of per capita GDP increased by over a half percentage point.

Similarly, analysis of country data from the data bases of world organizations such as the International Monetary Fund and the World Bank provide further evidence that corruption worsens income inequality and poverty (Gupta et al., 1998; Bhargava and Bolongaita, 2004; Tanzi and Davoodi, 1998) and hurts the poor most of all. Although, the argument that bribery may be viewed as payment of speed and efficiency for the rich, in countries with high levels of corruption the poor have to bribe even for access to basic services. Since they pay a higher proportion of their income on bribes, income inequality is exacerbated (Vittal, 2003). Thus, as Bhargava and Bolongaita (2004) contend, controlling corruption is then nothing less than promoting economic development, increasing country competitiveness, improving social conditions, and reducing poverty. However, dismantling corruption is no easy task. Most of the efforts in the past decade to address corruption typically began with an analysis of the underlying causes or enablers of corruption.

From an economic perspective, corruption arises from economic rent, which refers to "...the extra amount paid (over what would be paid for the best alternative use) to somebody or for something useful whose supply is limited either by nature or through human ingenuity" (Mauro, 1997, p. 2). According to this author, seeking economic rents by creating artificial limitations is an underlying source of corruption. Trade restrictions may be viewed as government induced sources of rent. Similarly, government subsidies, price controls, and multiple exchange rates are all potential sources of rent-seeking activities. In addition, restricted natural resources, low wages in civil service, and sociological divisions (such as ethnic divisions and loyalties) also enable corruption. Along the same lines, Kaufmann et al. (2003) identify three drivers of corruption:

- Monopoly of power, which refers to circumstances when public officials have absolute authority to enforce regulations and policies; 
- Discretion, refers to the ability of public officials to enforce regulations and policies in a discretionary manner;

- Lack of accountability and transparency, which refers to the lack of public official's accountability and transparency over their actions that enables them to exploit their power.

Analyzing the financial crises that occurred in Indonesia, Korea, and Thailand in the late 1990s, Bhargava and Bolongaita (2004) suggest that corruption was partly responsible. The authors claim that a lack of transparency and a weak banking system that was not prepared for financial liberalization, led to the financial crises. In addition, in his analysis of the causes of corruption, Tanzi (1998) distinguishes between the factors that affect demand for corruption and those that affect supply of corruption. He concludes that the circumstances that affect demand include regulations that restrict or create artificial limitations of goods and services, certain characteristics of tax systems, certain spending decisions, and price controls resulting in goods at below market prices. On the other hand, the factors that affect supply of corruption include rigid bureaucratic traditions, low level of public sector wages, weak or ineffectual penalty systems, institutional controls, lack of transparency of rule processes, and examples of corruption set by leaders. Although many policy analysts emphasize the public sector as a primary enabler of corruption (e.g., Mauro, 1997; Tanzi, 1998; Kauffman et al., 2000), similar conditions of discretionary power and lack of accountability occur in the private sector too. As Tanzi (1998) describes, privatization can create its own conditions to enable corruption, through payment of commissions to get access to markets and insider information not available to others that promote corruption in response to market competition.

Maor (2004) investigates two hypotheses related to transparency and accountability by a comparative analysis of five anticorruption mechanisms in the United States, the Soviet Union, Italy, and Australia (Queensland and New South Wales). First, he examines corruption investigations of senior officeholders following the creation of anticorruption mechanisms (e.g., commissions, special prosecutors, independent counsels, investigating judges) and hypothesizes that the outcome of this process is a concerted move by targeted political executives to undermine the credibility of anticorruption mechanisms and, when deemed necessary, to terminate their operation, and second, the extent to which the prosecutors are successful depends on both institutions and media accessibility: 
the more centralized and fused political power is, and the less media accessible the government is, the harder it will be to carry out an investigation. The hypotheses are strongly supported by the research and suggest that transparency and accountability are imperative to combat corruption. Kim et al. (2009) documented and evaluated an anti-corruption system called OPEN (Online Procedures Enhancement for civil application) in the Seoul Metropolitan Government. They utilized institutional theory and incorporated three distinctive (yet interrelated) dimensions of institutionalization (regulatory/coercive, cognitive/mimetic, and normative), and four anticorruption strategies embedded in the system to investigate how an e-government system for anticorruption in a local government has evolved. They found that in implementing such a system, the regulatory dimension was most effective, and (as in many IS implementations) strong leadership was crucial to its success.

Thus, we argue from the preceding discussion, that the conditions that promote public officials' discretionary and monopoly power to extract economic rents are core enablers of corruption. In addition, unless public officials face clear consequences for demanding and extracting economic rents, it is difficult to mitigate corruption, especially in developing countries where informality of bureaucratic processes and the lack of enforceable consequences maintain discretionary power. Clearly, then the discretionary and monopoly power of public officials to extract economic rents has to be dismantled and public institutions have to be to strengthened in order to enable accountability and transparency. If corruption is to be mitigated, the critical question remains: how can its enablers be targeted? In the next section, we argue that IT enabled egovernment can improve the transparency of the bureaucratic process and therefore, promote accountability.

\section{ICT ENABLED E-GOVERNMENT}

E-government has become an umbrella term covering all use of information technology in government (Torres et al., 2006) and includes IT-based sharing of information and conducting transactions within the government $(\mathrm{G} 2 \mathrm{G})$, between government and businesses (G2B), and between government and citizen (G2C). As noted by Singh et al., (2010), e-government “...entails streamlining operational processes, transcribing information held by government agencies into 
electronic form, linking disparate databases, and improving ease of access to services for members of the public" (p. 256). E-government has also been promoted as a strategy of public sector reform, with a focus on how it can improve the managerial process (Kudo, 2010).

Extant research on the evolution of e-government (West, 2004; Caba et al., 2005; Torres et al., 2006; Christou and Simpson, 2009) focus on the numerous factors that influence the growth of e-government in the past decade and found that income levels, strength of institutions and the commitment of the government to promoting e-government were the most important factors. Other studies focus on the factors that determine the level of development of e-government (Kim, 2007; Siau and Long, 2006) and suggest that one of the most important factors was the economic growth of the country. Rodriguez et al. (2011) examine socioeconomic factors (economic development. technological development, and education) and characteristics of public agencies (organizational complexity, institutional capacity, degree of leverage, administrative effectiveness and control of corruption) to examine the influence of such factors on the development of egovernment. Their results differ from earlier studies and suggest that economic growth was not an important factor but the characteristics of public agencies such as effectiveness and fulfillment of programs and public policies efficiently, effectively and responsibly were necessary for the implementation and development of e-government. They also conclude that the control of corruption does not encourage the development of e-government. Finally, Bertot et al. (2010) study the potential impacts of ICT (specifically e-government and social media) on cultural attitudes about transparency. They suggest that a culture of openness must be embedded within the governance system. In addition, this must be combined with technical and social capabilities to truly implement e-government transparency initiatives (Bertot et al., 2010).

Literature that focus on e-government initiatives to target corruption, (Hopper et al., 2009) suggest that electronic delivery of services (e.g., submitting internet applications and tax returns for computer processing) can reduce corruption by reducing interactions with officials, speeding up decisions, and reducing human errors. Similarly, in reviewing the literature to identify the potential role of egovernment in reducing corruption, Singh et al., (2010) emphasize that egovernment eliminates discretion from the equation by removing intermediary 
services and allowing citizens to conduct transactions themselves. Andersen and Rand (2006) also study the relation between corruption and e-government and examine a cross-section of countries from the 1997 to 2002 period. They conclude that well-designed ICT policies are likely to be effective in the fight against corruption. Shin and Eom (2008) focus on the impacts of bureaucratic professionalism, bureaucratic quality and law enforcement through the use of national level data and find that both e-government and traditional anti-corruption factors have a positive impact on reducing corruption. In a follow up article, Shim and Eom (2009) examine the impact of ICT and social capital on corruption and argue that ICT has the potential to reduce unnecessary human intervention in government work processes, which reduces the need to monitor corrupt behavior. They used panels of datasets from various sources and concluded that ICT is an effective tool for reducing corruption and social capital also has positive effects on reducing corruption, although the relationship between social capital and ICT is inconclusive.

To summarize, an important strategy for dismantling corruption can be the providing of easy access to information for all citizens through the use of egovernment initiatives. This can result in greater transparency that reduces the ability of the public sector official to demand bribes. Thus, e-government can not only provide greater information to the population but also remove the discretion of the public official and allow citizens to conduct transactions themselves which, in turn, could lead to a reduction in corruption.

This leads to the following hypothesis:

H1: The use of e-government will result in mitigating corruption in developed and developing countries.

\subsection{E-government, economic growth and corruption in developed and developing countries}

Extant research has focused on the relationship between ICT related e-government and corruption in developing countries and has provided case studies that show first, corruption is rampant in developing countries and second, corruption can be mitigated through good governance. In addition, there have been recent case studies of country-specific policies and initiatives, for example in China (Lan, 
2004; Zhang and Zhang, 2009) and India (Mistry, 2012). In a valuable review of the literature on public sector performance measurement, Mimba et al. (2007) indicate that the public sector in developing countries is often characterized by low-institutional capacity, limited involvement of stakeholders, high levels of corruption, and informality (or lack of formal rules and procedures). They further identify weaknesses in regulatory practice, a low level of public accountability, and a lack of transparency as underlying the informality of processes that lead to bureaucratic corruption.

Kimbro's (2002) analysis indicates that countries that have better laws, a more effective judiciary, good financial reporting standards, and a higher concentration of accountants were found to be less corrupt. Thus, developed countries that have stronger legal systems, better equipped institutions that reduce the monopoly power of public officials and greater transparency may experience a lesser drop in corruption through the greater use of e-governance than developing countries. Kim (2007) explores the determinants of global e-government performance and concludes that countries with high e-government performance are likely to be the wealthy, developed and Western countries. He analyzes factors such as economic wealth, education, urbanization, civil liberties, government effectiveness and the interaction between internet usage and economic wealth and finds that the extent of internet penetration alone does not determine e-government performance (Kim, 2007).

Focusing on e-government initiatives to target corruption, Hopper et al. (2009) suggest that electronic delivery of services (e.g., submitting internet applications and tax returns for computer processing) can reduce corruption by reducing interactions with officials, speeding up decisions, and reducing human errors. Similarly, in reviewing the literature to identify the potential role of e-government in reducing corruption, Singh et al., (2010) note that because e-government promotes multiple objectives, the goal to reduce corruption can be lost unless the priority on transparency and accountability is not consciously built into the public service delivery system from the planning and design phase itself. In a similar vein, Barata and Cain (2001) emphasize the use of information technology, to digitalize public services or functions, does not in and of itself ensure transparency and accountability. Both need to be grounded in accurate and reliable record keeping, which in turn depends upon clear and well enforced 
norms and regulations. As Hopper et al. (2009) note in their review of public sector performance, publishing monthly intergovernmental fund transfers in the Ugandan local media reduced fund losses by 78 per cent. Public access to information on public sector performance supports the demand for accountability as an expected norm.

To summarize, extant research in developed countries indicates that the drivers of corruption, such as monopoly of power, discretion and the lack of accountability and transparency are mitigated by the existence of strong legal systems, better equipped institutions and greater transparency (Mistry, 2012). Hence we argue this may have led to reduced levels of corruption as these determinants can be impacted by the greater or more efficient use of egovernment initiatives that could result in a reduction of the monopoly power of officials and ultimately lead to transparency and accountability (Kimbro, 2002; Kim, 2007). Further, existing research on the prevalence of the enablers of corruption (such as weaker legal systems, lack of transparency and the discretionary power of public officials) in developing countries suggests that it is in these countries that e-government has the greatest potential for mitigating corruption. Hence, we argue that the impact of e-government on corruption will be greater in developing countries. This leads to the following hypothesis:

H2: The impact of e-government on corruption will be higher in developing countries than in developed countries.

\section{DATA AND METHODOLOGY}

To examine the hypotheses developed in the last section, we consider wellestablished and internationally recognized measures of corruption and egovernment. In addition, to test the validity of our hypotheses, we depend on Ordinary Least Squares (or OLS) regression models. In the next section, we first describe the measures and our empirical methodology before discussing the results.

\subsection{Measure of Corruption}

We use the Corruption Perception Index (CPI) compiled by Transparency International (TI) to develop our measure of corruption. TI conducts annual surveys to capture the abuse of entrusted power for private gain in both public and 
private sectors on a scale of 0 to 10 , with lower values indicating greater corruption. In essence, this measure reflects the systemic corruption prevalent in a country. The CPI is uniquely qualified for our research as it is not a single survey, but a comprehensive survey carried out by independent and reputable institutions. For most countries, the index is based on 14 different annual expert and business surveys (Table 1). As a result, the measurements encompass a diverse array of issues related to corruption, such as the bribery of public officials, kickbacks in public procurement, embezzlement of public funds, and the effectiveness of public sector anti-corruption efforts. Further, these surveys are conducted each year, enabling the measurement of a country's level of corruption at a particular time and thus, can capture the direction of changes in corruption in a particular country. In this study, we attempt to examine not only the relationship between corruption and e-government, but also if changes in e-government are related to changes in corruption.

\begin{tabular}{|r|r|}
\hline 1. & African Development Bank Governance Ratings. \\
\hline 2. & Asian Development Bank Country Performance Assessment. \\
\hline 3. & Bertelsmann Foundation Sustainable Governance Indicators. \\
\hline 4. & Bertelsmann Foundation Transformation Index. \\
\hline 5. & Economist Intelligence Unit Country Risk Assessment. \\
\hline 6. & Freedom House Nations in Transit. \\
\hline 7. & Global Insight Country Risk Ratings. \\
\hline 8. & IMD World Competitiveness Year Book. \\
\hline 9. & Political and Economic Risk Consultancy Asian Intelligence. \\
\hline 10. & Political Risk Services International Country Risk Guide. \\
\hline 11. & Transparency International Bribe Payers Survey. \\
\hline 12. & World Bank - Country Performance and Institutional Assessment. \\
\hline 13. & World Economic Forum Executive Opinion Survey (EOS). \\
\hline 14. & World Justice Project Rule of Law Index. \\
\hline
\end{tabular}

Table 1: Measure of Corruption: annual expert and business surveys

\subsection{Measure of e-government}

Global e-government Readiness Index, later renamed e-government Development Index (EDI), is used to obtain the measure of a country's e- 
government. This measure is based on surveys conducted in collaboration between the UN Department of Economic and Social Affairs (UNDESA) and the Civic Resource Group (CRG), a private sector consulting firm providing technology solutions in e-government. The framework of EDI was envisioned as part of the UN Millennium Declaration and encompasses both the state of egovernment readiness and the extent of e-participation. It reflects how a country is using "information technologies to promote access and inclusion of its people."

The EDI is a composite of three different indices - (1) the Web Measure Index, (2) the Telecommunication Infrastructure Index and (3) the Human Capital Index. The Web Measure Index represents the generic aptitude of governments to employ e-government as a tool to inform, interact, transact and network. The Telecommunication Infrastructure Index defines a country's ICT infrastructure capacity. Finally, the Human Capital Index relies on the United Nations Development Program (UNDP) education index, measuring the level of development of the human capital within a country.

The EDI was released for the first time in 2003 and has been reevaluated in 2004, 2005, 2008, 2010 and 2012. For the purpose of this study, we compare EDI in 2003 and 2010. We compare these years because the impact of changes in ICT on the changes in corruption are best examined over time. The seven year difference should enable us to capture the effects of changes to ICT on corruption, if any. Although the e-government survey for 2012 can be accessed, other relevant data that we need for our analysis is not yet available and thus, we depend on the earlier e-government survey of 2010.

\subsection{Measure of Economic Development}

As discussed earlier, the level of economic development is significantly associated with corruption reduction. As the quality of life improves in different countries, corruption tends to decrease. Further, developed countries have significant resources to devote towards fighting corruption. As a result, it can be argued that changes in corruption may only be caused by the economic development of the country and ICT may not be associated with corruption. To examine this question, we want to establish a relationship between corruption reduction and increased ICT after controlling for the effects of economic 
development. Thus, economic development was controlled, by including the natural logarithm of per capita real GDP of the countries. We take the natural log transformation of the inflation-adjusted values of per capita GDP to pull outliers from a positively skewed distribution closer to the bulk of the data. The data are from the World Bank's database named the World Development Indicators.

\subsection{Other Control Variables}

In addition to the previously mentioned three measures, we use other control variables in some of our regressions to account for additional forces that may impact corruption. Specifically, we use Black Market Premium, Bureaucracy, and Civil Rights. We follow Levine (2005), who found these variables to be significant determinants of the economic characteristics of different countries. Black Market Premium refers to the amount in excess of the official exchange rate that must be paid to purchase foreign exchange on an illegal (black) market. Bureaucracy measures the quality of government bureaucracy. High scores indicate autonomy from political pressures and strengths and expertise to govern without drastic changes in policy. Civil Rights is an index of civil liberties and political freedom.

\subsection{Empirical Methodology}

In our empirical analyses, we first examine the relationship between EDI and CPI in two time periods (i.e. 2003 and 2010). Then we explore if there is a relationship between the change in EDI during this seven year period and the change in CPI during the same time period. Finally, in an attempt to establish causational relationship, we utilize a probit regression methodology.

To establish the relationship between EDI and CPI, we estimate the following OLS regression equation:

Corruption $=\alpha+\beta * e-$ government $+\gamma *$ CountryDevelopment $+\varepsilon$

where Corruption is the corruption perception index in 2010, e-government is the E-government Development Index in 2003 and CountryDevelopment is the natural $\log$ of GDP in 2003. This equation will test the relationship between corruption and ICT or e-government after controlling for country development or GDP. We use an OLS regression methodology with robust standard errors. These 
Huber-White robust standard errors are intended to control for the possible presence of Heteroscedasticity in the sample.

Next, we estimate the following empirical model:

$\Delta$ Corruption $=\alpha+\beta * \Delta e-$ government $+\gamma *$ CountryDevelopment

$+\delta * \Delta e-$ government $*$ CountryDevelopment $+\varepsilon$

where $\Delta$ Corruption is the change in corruption perception index between 2003 and 2010, $\Delta$ e-government is the change in e-government development index between 2003 and 2010. Finally, CountryDevelopment is the natural log of GDP in 2003. We estimate equation (2) to examine if change in ICT (as measured by the change in the e-government Index between two pre-specified years) is linked to change in corruption (as measured by the change in the Corruption Perception Index between two pre-specified years). Equation (2) is frequently referred to as the Difference-in-Differences or Double Difference Estimator, and the results are considered stronger as this methodology does not suffer from endogeneity issues due to omitted variable bias. Since it is not possible to identify all possible observable and unobservable variables that may affect corruption, a Double Difference Estimator will provide us with the best possible results. Second, the presence of the interaction term $\Delta e$-government*CountryDevelopment will allow us to test which countries, developing or developed, benefit most from increased use of ICT. It is important to note that this interaction term introduces non-linearity in the model. The term $\beta^{*} \Delta e$-government will capture the firstorder effects of e-government on corruption. In addition, the term $\delta * \Delta e-$ government $*$ CountryDevelopment will evaluate whether a higher level of country development magnifies or diminishes the effects of e-government on corruption. From our discussion presented above, we argue that developing countries should benefit the most from the increased use of ICT. Thus, we should observe a negative coefficient estimate of $\delta$. Finally, to further test the strength of the relation between e-government and corruption, we consider dependent and independent variables from two different time periods. We split our sample in two different intervals - 2003 to 2008 and 2008 to 2010. While the exact mid-point of our sample would have been 2007, no e-government Development Index was published in either 2006 or 2007. However, 2008 has another particular 
significance - it is near the starting point of the global recession. Therefore, this test could enable us to determine whether corruption reduction following the financial crisis is related to an increase in ICT before the crisis. We utilize a Probit regression methodology. In a Probit model, the dependent variable is dichotomous (that is, the outcome is either 0 , meaning failure, or 1 , meaning success). The estimated coefficients of the independent variables can be used to calculate the incremental probability of success. In our tests, as the dependent variable, we utilize a dummy variable Reduction in Corruption, with 1 indicating that the country has improved in CPI scores during 2008 and 2010 (meaning a reduction in corruption). The independent variable \% Change in EDI03-08 is the percentage change in e-government Development Index over 2003 and 2008.

\section{RESULTS}

Summary statistics of the relevant variables are presented in Table 2. Since we need data on CPI, EDI and GDP in both 2003 and 2010 to conduct regression analyses, our final sample includes 108 countries. See Annex for a complete list.

\begin{tabular}{|c|c|c|c|c|c|}
\hline Variable & Mean & $25^{\text {th }}$ Percentile & Median & $75^{\text {th }}$ Percentile & $\begin{array}{l}\text { Number of } \\
\text { Observations }\end{array}$ \\
\hline CPI in 2003 & 4.45 & 2.50 & 3.70 & 6.00 & 108 \\
\hline EDI in 2003 & 0.46 & 0.33 & 0.43 & 0.59 & 108 \\
\hline GDP in 2003 & 8329 & 899 & 2736 & 12204 & 108 \\
\hline CPI in 2010 & 4.43 & 2.65 & 3.50 & 6.10 & 108 \\
\hline EDI in 2010 & 0.50 & 0.38 & 0.48 & 0.62 & 108 \\
\hline GDP in 2010 & 9273 & 1304 & 3372 & 13342 & 108 \\
\hline$\%$ Change in CPI & 2.24 & -9.09 & -1.13 & 9.81 & 108 \\
\hline$\%$ Change in EDI & 13.99 & 0.03 & 11.52 & 23.73 & 108 \\
\hline$\%$ Change in GDP & 24.41 & 9.15 & 21.12 & 32.84 & 108 \\
\hline Black Market Premium & 23.44 & 0.00 & 7.82 & 26.28 & 61 \\
\hline Bureaucracy & 3.75 & 2.89 & 3.43 & 5.64 & 61 \\
\hline Civil Rights & 2.85 & 1.00 & 2.00 & 4.40 & 61 \\
\hline $\begin{array}{l}\text { CPI is on a scale of } 1 \text { to } \\
\text { EDI is on a scale of } 0 \text { to } \\
\text { GDP is the real per capit } \\
\% \text { Change in CPI is the } \\
\text { Similarly, \% Change in } \\
\text { respectively. } \\
\text { Black Market Premium } \\
\text { exchange on an illegal ( } \\
\text { Bureaucracy measures th } \\
\text { Civil Rights is an index }\end{array}$ & $\begin{array}{l}\text { higher } \\
\text { higher va } \\
\text { lomestic } \\
\text { ge chang } \\
\text { \% Chan } \\
\text { the amo } \\
\text { arket. } \\
\text { of gov } \\
\text { berties }\end{array}$ & $\begin{array}{l}\text { indicating lower } \\
\text { indicating greater } \\
\text { luct in U.S. dollar } \\
\text { CPI values over } 2 \\
\text { GDP are percent } \\
\text { excess of the off } \\
\text { ent bureaucracy. } \\
\text { olitical freedom. }\end{array}$ & $\begin{array}{l}\text { Is of corru } \\
\text { vernment } \\
\text { hanges } 2010 . \\
\text { hange in } \\
\text { exchange }\end{array}$ & $\begin{array}{l}\text { and GDP over } 20 \\
\text { hat must be paid }\end{array}$ & 2010, \\
\hline
\end{tabular}


Correlation Matrix:

\begin{tabular}{|c|c|c|c|c|c|c|c|c|c|c|c|}
\hline & $\begin{array}{c}\text { CPI } \\
\text { in } \\
2003\end{array}$ & $\begin{array}{c}\text { EDI } \\
\text { in } \\
2003\end{array}$ & $\begin{array}{c}G D P \\
\text { in } \\
2003 \\
\end{array}$ & $\begin{array}{c}\text { CPI } \\
\text { in } \\
2010\end{array}$ & $\begin{array}{c}\text { EDI } \\
\text { in } \\
2010\end{array}$ & $\begin{array}{l}\text { GDP } \\
\text { in } \\
2010\end{array}$ & $\begin{array}{c}\% \\
\text { Change } \\
\text { in CPI }\end{array}$ & $\begin{array}{c}\% \% \\
\text { Change } \\
\text { in EDI }\end{array}$ & $\begin{array}{c}\% \\
\text { Change } \\
\text { in GDP }\end{array}$ & $\begin{array}{c}\text { Black } \\
\text { Market } \\
\text { Prem }\end{array}$ & $\begin{array}{c}\text { Bure } \\
\text { aucra } \\
\text { cy }\end{array}$ \\
\hline $\begin{array}{l}\text { EDI in } \\
2003\end{array}$ & $0.89 *$ & 1 & & & & & & & & & \\
\hline $\begin{array}{l}\text { GDP in } \\
2003\end{array}$ & $0.87 *$ & $0.87^{*}$ & 1 & & & & & & & & \\
\hline $\begin{array}{l}\text { CPI in } \\
2010\end{array}$ & $0.98^{*}$ & $0.87 *$ & $0.88^{*}$ & 1 & & & & & & & \\
\hline $\begin{array}{l}\text { EDI in } \\
2010\end{array}$ & $0.89^{*}$ & $0.94 *$ & $0.87 *$ & $0.87 *$ & 1 & & & & & & \\
\hline $\begin{array}{l}\text { GDP in } \\
2010\end{array}$ & $0.87 *$ & $0.88^{*}$ & $0.99^{*}$ & $0.88^{*}$ & $0.87 *$ & 1 & & & & & \\
\hline $\begin{array}{l}\% \text { Change } \\
\text { in CPI }\end{array}$ & $\begin{array}{c}- \\
0.34 *\end{array}$ & $\begin{array}{c}- \\
0.31 *\end{array}$ & -0.21 & -0.18 & $0.32 *$ & -0.21 & 1 & & & & \\
\hline $\begin{array}{l}\text { \% Change } \\
\text { in EDI }\end{array}$ & $0 . \overline{34 *}$ & $0.53 *$ & $0 . \overline{32} *$ & $0 . \overline{33} *$ & $\overline{-} \cdot \overline{25}$ & $-\overline{33} *$ & $0.27 *$ & 1 & & & \\
\hline $\begin{array}{l}\text { \% Change } \\
\text { in GDP }\end{array}$ & $\overline{-}-$ & $\overline{-}^{-}$ & $\overline{0.54 *}$ & $0.48^{*}$ & $0.44^{*}$ & $\overline{-}-\overline{1}$ * & $0.29 *$ & $0.24 *$ & 1 & & \\
\hline $\begin{array}{l}\text { Black } \\
\text { Market } \\
\text { Premium }\end{array}$ & $0.54 *$ & $0 . \overline{5} *$ & $0 . \overline{4} 5^{*}$ & $0 . \overline{50 *}$ & $0.53^{*}$ & $0 . \overline{-}$ & $0.52 *$ & $0.31 *$ & $0.32 *$ & 1 & \\
\hline $\begin{array}{l}\text { Bureaucra } \\
\text { cy }\end{array}$ & $0.83^{*}$ & $0.78^{*}$ & $0.81 *$ & $0.81 *$ & $0.76^{*}$ & $0.81^{*}$ & $-0.30^{*}$ & $-0.40^{*}$ & $-0.53 *$ & $-0.57 *$ & 1 \\
\hline $\begin{array}{l}\text { Civil } \\
\text { Rights }\end{array}$ & $-\overline{6} 1^{-}$ & $-\overline{62 *}$ & $0.67 *$ & $0.57 *$ & $-\overline{-}$ & $-\overline{-}$ & $0.28 *$ & $0.26^{*}$ & $0.40^{*}$ & $0.31 *$ & $-\overline{-}$ \\
\hline
\end{tabular}

Table 2: Summary Statistics (continuation)

In Table 3, we split our sample in four different income quartiles using per capita real GDP in 2003. In the lowest quartile, we have the least developed countries. Among them, the correlation between a \% Change in EDI and a \% Change in CPI is 0.3648. In the second quartile, the correlation decreases to 0.2434 . In the third quartile, the correlation is only 0.1960 . Finally, in the fourth quartile (includes the most developed countries), the correlation decreases to 0.1830. This indicates that the least developed countries benefitted most from increased ICT in the seven-year period between 2003 and 2010. In the next section, we will present regression analyses that support these results.

\begin{tabular}{lr}
\hline \hline GDP in 2003 & Correlation \\
Quartile & $0.3648^{*}$ \\
\hline \hline Lowest Quartile & $0.2434^{*}$ \\
$2^{\text {nd }}$ Quartile & $0.1960^{*}$ \\
$3^{\text {rd }}$ Quartile & $0.1830^{*}$ \\
Highest Quartile & \\
\hline \hline$*$ denotes statistical significance at the 10\% level. \\
\hline \hline
\end{tabular}

Table 3: Correlation between \% Change in CPI and \% Change in EDI 


\subsection{Relationship between Corruption and e-goverment}

In Figure 1, we plot the e-government Development Index in 2003 on the horizontal axis and the Corruption Perception Index in 2003 on the vertical axis. As mentioned before, higher values of EDI indicate better preparedness and higher values of CPI indicate lower corruption. Therefore, we expect to observe a positive relationship if corruption decreases as ICT increases. This positive relationship is depicted in the graph in Figure 1. We also draw a linear "best-fit" line through our observations, which suggests that there may be a positive relationship. In Figure 2, we repeat the same exercise with data from 2010. That is, we plot the EDI in 2010 in the horizontal axis and the CPI in 2010 in the vertical axis. As expected, we observe a positive relationship Next, we concentrate on how changes in EDI may affect changes in CPI. In Figure 3, we plot the percentage change in EDI between 2003 and 2010 on the horizontal axis and the percentage change in CPI between 2003 and 2010 on the vertical axis. This graph essentially captures the evolution of CPI and EDI over the sample period. We also draw a linear best-fit line through the data. It is clear from the graph that not all countries that increased their e-government preparedness experienced a decrease in corruption. However, the best-fit line does have a positive slope.

\subsection{Regression Analyses}

To further examine and establish the relationship between Corruption and egovernment observed in the figures presented above and hypothesis 1 , we turn to empirical analysis and first estimate this regression equation with data from surveys in 2003 and 2010. The regression estimate using equation (1) is presented in model (1) of Table 4. In model (1) in Table 4, we estimate the relationship between CPI in 2010 and EDI in 2003. In this model, the dependent variable is CPI in 2010. We also include a measure of the level of country development, and the logarithm of real per capita GDP in 2003 as a control variable. The coefficient estimate for EDI in 2003 is positive and statistically significant. Hence, hypothesis 1 discussed earlier is supported. However, as shown in Table 4, due to the correlation between the EDI and LnGDP, we have to investigate the relationship between corruption and e-government further by not depending on the levels of corruption and e-government but focusing on the changes. Hence, as 
depicted in the following section, the next model we investigate focuses on the changes in these variables to support our hypothesis.

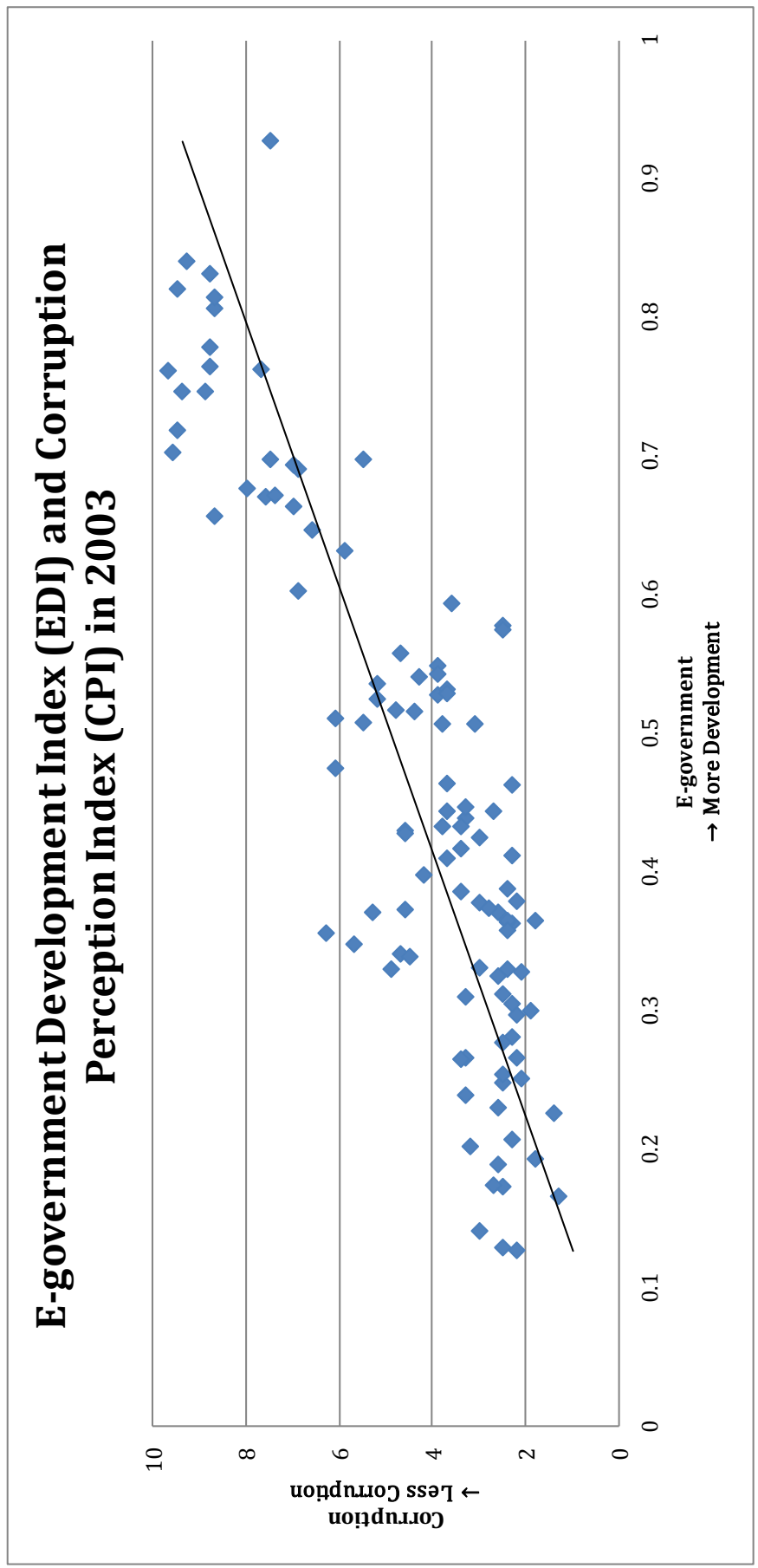

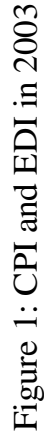




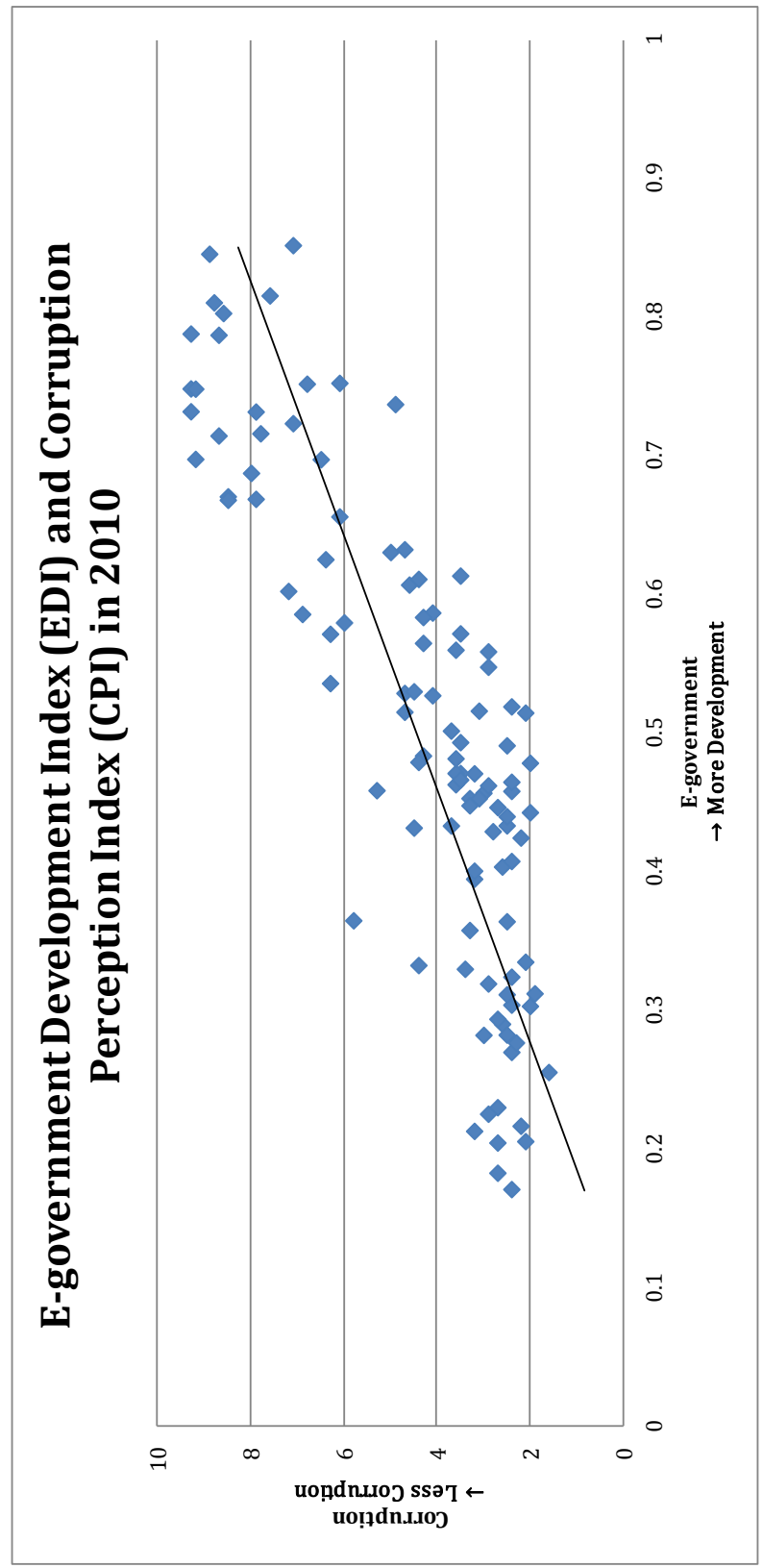

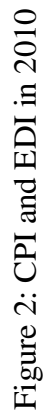




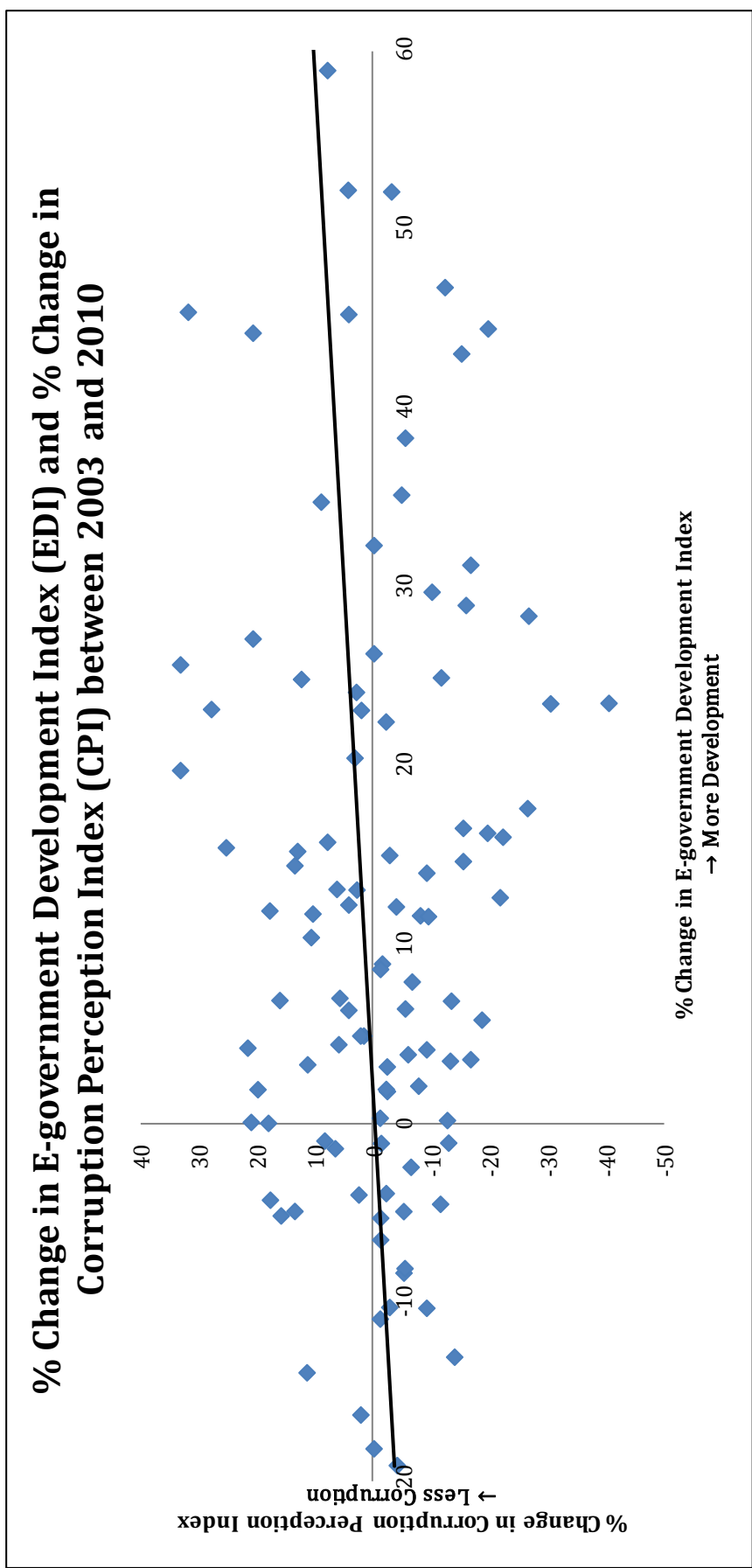

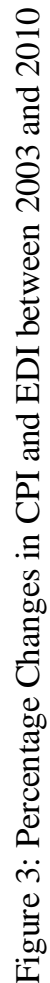




\begin{tabular}{|c|c|c|c|c|}
\hline Dependent Variable: & $\begin{array}{c}\text { Model (1) } \\
\text { CPI in } 2010\end{array}$ & $\begin{array}{c}\text { Model (2) } \\
\text { \% Change } \\
\text { in CPI }\end{array}$ & $\begin{array}{c}\text { Model (3) } \\
\% \text { Change } \\
\text { in CPI }\end{array}$ & $\begin{array}{r}\text { Model (4) } \\
\text { Reduction in } \\
\text { Corruption }\end{array}$ \\
\hline EDI in 2003 & $\begin{array}{l}5.6320 \\
(1.1551)^{* * * *}\end{array}$ & & & \\
\hline LnGDP2003 & $\begin{array}{l}0.6303 \\
(0.1335)^{* * *}\end{array}$ & $\begin{array}{l}-0.6136 \\
(1.2794)\end{array}$ & $\begin{array}{l}-0.4617 \\
(2.3390)\end{array}$ & $\begin{array}{r}0.2477 \\
(0.2497)\end{array}$ \\
\hline$\%$ Change in EDI & & $\begin{array}{l}1.1674 \\
(0.7010)^{*}\end{array}$ & $\begin{array}{l}2.3109 \\
(0.8149)^{* * * *}\end{array}$ & \\
\hline LnGDP2003 * \% Change in EDI & & $\begin{array}{l}-0.1406 \\
(0.0824)^{*}\end{array}$ & $\begin{array}{l}-0.2997 \\
(0.1068) * * *\end{array}$ & \\
\hline$\%$ Change in EDIO3-08 & & & & $\begin{array}{r}0.0115 \\
(0.0055)^{* *}\end{array}$ \\
\hline LnGDP2003 *\% Change in EDIO3-08 & & & & $\begin{array}{r}-0.0015 \\
(0.0007)^{* *}\end{array}$ \\
\hline Black Market Premium & & & $\begin{array}{c}0.1638 \\
(0.1011)\end{array}$ & $\begin{array}{r}0.0062 \\
(0.0066)\end{array}$ \\
\hline Bureaucracy & & & $\begin{array}{c}0.6834 \\
(2.0258)\end{array}$ & $\begin{array}{l}-0.0949 \\
(0.1902)\end{array}$ \\
\hline Civil Rights & & & $\begin{array}{c}0.7433 \\
(1.6708)\end{array}$ & $\begin{array}{r}0.0821 \\
(0.1504)\end{array}$ \\
\hline Constant & $\begin{array}{l}-3.2023 \\
(0.6801)^{* * *} \\
\end{array}$ & $\begin{array}{c}4.9508 \\
(11.8659) \\
\end{array}$ & $\begin{array}{c}-3.3285 \\
(20.9724) \\
\end{array}$ & $\begin{array}{c}-2.6091 \\
(2.3145) \\
\end{array}$ \\
\hline Observations & 108 & 108 & 61 & 58 \\
\hline R-squared & 0.78 & 0.10 & 0.41 & 0.22 \\
\hline
\end{tabular}

This table reports OLS regressions with robust standard errors in Model (1), Model (2) and Model (3).

Model (3) includes additional control variables.

Black Market Premium refers to the amount in excess of the official exchange rate that must be paid to purchase foreign exchange on an illegal (black) market.

Bureaucracy measures the quality of government bureaucracy.

Civil Rights is an index of civil liberties and political freedom.

This table also reports the results of a Probit regression (Model 4), with robust standard errors.

The dependent variable Reduction in Corruption is a dummy variable with 1 indicating that the country has improved in CPI scores during 2008 and 2010 (meaning a reduction in corruption). The independent variable \% Change in EDI03-08 is the percentage change in E-government Development Index over 2003 and 2008.

The standard errors are reported in the parenthesis.

$*, * *$ and $* * *$ represent statistical significance at the $10 \%, 5 \%$ and $1 \%$ respectively.

Table 4: Regression Analyses - Comparing Changes in Corruption to Changes in ICT

Model 1

\begin{tabular}{|l|r|r|}
\cline { 2 - 3 } \multicolumn{1}{c|}{} & LnGDP2003 & EDI in 2003 \\
\hline LnGDP2003 & 1 & \\
\hline EDI in 2003 & 0.9115 & 1 \\
\hline
\end{tabular}

Models 2 and 3:

\begin{tabular}{|l|r|r|r|r|r|r|}
\cline { 2 - 7 } \multicolumn{1}{c|}{} & $\begin{array}{r}\text { LnGDP } \\
2003\end{array}$ & $\begin{array}{r}\text { \% Change } \\
\text { in EDI }\end{array}$ & $\begin{array}{r}\text { LnGDP2003*\% } \\
\text { Change in EDI }\end{array}$ & $\begin{array}{r}\text { Black Market } \\
\text { Premium }\end{array}$ & $\begin{array}{r}\text { Bureauc } \\
\text { racy }\end{array}$ & $\begin{array}{r}\text { Civil } \\
\text { Rights }\end{array}$ \\
\hline LnGDP2003 & 1 & & & & \\
\hline $\begin{array}{l}\text { LnGDP2003 } * \% \\
\text { Change in EDI }\end{array}$ & -0.34 & 1 & & & \\
\hline Black Market Premium & -0.59 & 0.69 & 0.31 & 0.26 & & \\
\hline Bureaucracy & 0.76 & -0.40 & -0.39 & -0.57 & \\
\hline Civil Rights & -0.69 & 0.26 & 0.23 & & \\
\hline
\end{tabular}




\begin{tabular}{|l|r|r|r|r|r|r|}
\cline { 2 - 7 } & LnGDP2003 & $\begin{array}{r}\text { Model 4: } \\
\text { in EDI03-08 }\end{array}$ & $\begin{array}{r}\text { LnGDP2003 } \\
\text { in EDI03-08 } \\
\text { in EDInge }\end{array}$ & $\begin{array}{r}\text { Black } \\
\text { Market } \\
\text { Premium }\end{array}$ & Bureaucracy & Civil Rights \\
\hline LnGDP2003 & 1 & & & & & \\
\hline$\%$ Change in EDI03-08 & -0.13 & 1 & & & & \\
\hline $\begin{array}{l}\text { LnGDP2003*\% } \\
\text { Change in EDI03-08 }\end{array}$ & -0.10 & 0.69 & 1 & & & \\
\hline Black Market Premium & -0.63 & 0.03 & 0.01 & & & \\
\hline Bureaucracy & 0.78 & -0.12 & -0.09 & -0.59 & & \\
\hline Civil Rights & -0.70 & 0.04 & 0.01 & 0.35 & -0.69 & \\
\hline
\end{tabular}

Table 4: correlation tables (continuation)

\subsection{Significance of Improvements in ICT}

We present the regression estimates using equation (2) in model (2) of Table 4. In model (2) of Table 4, we use \% Change in CPI as the dependent variable and \% Change in EDI as the independent variable of interest. Again, we observe a positive and statistically significant coefficient of \% Change in EDI. These regressions support hypothesis 1 that changes in the use of e-government will result in changes in corruption in both developed and developing countries. In addition, we can utilize the regression estimate in model (2) of Table 4 to compute the economic significance of improvements in ICT on reductions in corruption. The coefficient of \% Change in EDI is 1.1674. This means that, holding everything else constant, a $1 \%$ change in EDI leads to a $1.17 \%$ decrease in corruption.

\subsection{Which Countries benefit more from increased ICT?}

Using the data available on EDI, CPI and GDP, in order to test hypothesis 2, we explore which countries benefit more from the increased use of ICT. Since developing countries tend to have less transparency in the public sector and greater corruption, these countries should benefit the most from improved ICT. The coefficient estimate of the interaction term $\Delta e$ - government* CountryDevelopment (as represented by the term LnGDP2003 * \% Change in EDI in the regression table) is negative and statistically significant in model (2) of Table 4. This means that as the values of LnGDP2003 increase, 
ICT improvements play a relatively lesser role in reducing corruption. In other words, developing nations benefit most from improvements in ICT and our hypothesis is supported.

We also conducted robustness tests to see whether the level of corruption in a country itself has a significant impact on the effects of e-government on corruption. That is, could e-government be a tool to maintain no corruption in a society without corruption, but with the same power or less power than those that have corruption and need it to be removed. To this end, we estimate our regressions equations with \% Change in EDI and CPI in $2003 * \%$ Change in EDI included as independent variables. The results show that there is a positive and statistically significant coefficient of \% Change in EDI. On the other hand, there is a negative and statistically significant coefficient of CPI in $2003 * \%$ Change in $E D I$. This indicates that even in countries with low corruption, e-government can help lower corruption further. However, the benefits of e-government on corruption reduction are highest in the most corrupt countries.

\subsection{Additional Control Variables}

Third, we estimate equation (2) with the additional control variables discussed earlier that may affect corruption reduction efforts. As the model (3) in Table 4 shows, our results involving the relationship between corruption and egovernment continue to hold and support our hypothesis.

\subsection{Probit Model}

Finally, to establish a causational relationship between EDI and CPI, we estimate a probit regression model. As described above, we split our sample in two different intervals - 2003 to 2008 and 2008 to 2010. Through this exercise, we can test whether corruption reduction following the financial crisis is related to an increase in ICT before the crisis. The dependent variable Reduction in Corruption is a dummy variable with 1 indicating that the country has improved in CPI scores during 2008 and 2010 (meaning a reduction in corruption). The regression estimates in Model (4) of Table 4 shows that higher ICT before the financial crisis increased the probability of reduction in corruption following the financial crisis. Our hypothesis regarding developing and developed countries' benefits from ICT is also supported. 


\section{DISCUSSION AND CONCLUSION}

In this paper, we first examine the relationship between e-government and corruption and then investigate if changes in the use of ICT are linked to changes in their levels of corruption. Our final hypothesis examines whether developed or developing countries benefit most from greater use of ICT or e-government. In order to examine these relationships we developed hypotheses and tested these hypotheses through the use of empirical models. The models supported the hypotheses and demonstrated that as the use of ICT or e-government increases corruption decreases. Specifically, the models suggest that a $1 \%$ increase in the egovernment Index may have resulted in a $1.17 \%$ decrease in corruption. We also found that developing countries benefitted the most from the increased use of ICT in the seven-year period between 2003 and 2010. We estimated the model with additional control variables in order to check for robustness and found that the results are supported. We also conducted a Probit test which shows that higher ICT before the financial crisis increased the probability of reduction in corruption following the financial crisis. Thus, our findings suggest that increased spending on e-government does result in a reduction in corruption in our sample. This suggests that the use of ICT does hold promise for the reduction of corruption in both developed and developing countries. The unique contribution of our empirical analysis is as follows. First, although others have investigated the relationship between corruption and e-government (Mauro, 1997: Andersen and Rand, 2006; Shim and Eom, 2008), to the best of our knowledge, we are the first to establish causation for this important relationship. We achieve this through the use of a Probit model that not only establishes the causative relationship but also supports our hypotheses that the increased use of e-government before the economic crisis of 2008 resulted in a drop in corruption in later years. Second, these studies have not examined how changes in e-governance are related to changes in corruption. We examine this important link and show that a $1 \%$ increase in the e-government Index may result in a $1.17 \%$ decrease in corruption. In addition, our study differentiates between corruption in developed versus developing countries, as we utilize a nested empirical model through the use of an interaction term and test which countries - developed or developing countries benefit most from corruption reduction efforts. 
In addition, our focus on e-government in mitigating corruption is timely in the current global context of increased interest in attenuating the economic divide within and across countries, and promotion of good governance and social responsibility. In this context, the paper's contribution is significant because there is increasing recognition that problems, especially in the developing world, can only be solved by bringing similar disciplinary perspectives to bear on them. Economic perspectives undergird the argument that corruption hinders economic development and therefore must be addressed, especially in the developing world. Understanding the underlying forces that enable and sustain corruption require an analysis of good governance and the role of public institutions and policies. The model tested in this paper can be utilized to analyze how corruption can be mitigated through sound policies of transparency and accountability. The model also highlights the critical role that government and other public institutions have to play in dismantling the forces that sustain corruption.

Finally, another contribution of the paper is the specific application of the model to analyze differences between developed and developing countries in their efforts to reduce corruption. Our finding that IT enabled e-government does result in reduced corruption offers a promising glimpse of the power of IT enabled egovernment in developing countries to mitigate corruption and whether such investments live up to their promise of offering transparency and accountability. In utilizing comprehensive and well recognized data from external assessments, and by conducting a Probit test that establishes causation, this paper goes beyond most analysis of corruption in documenting how e-government initiatives can be effective in reducing corruption.

One of the limitations of our research focuses on intra-country comparisons, since not all sectors or industries within an economy are affected equally by spending on ICT enabled e-government. Second, the conditions that enable corruption vary with the historical, political, economic, and public sector policies of countries. Third, although the indices we use (EDI and CPI) are well established and well recognized around the world, the indices are comprised of different indices that may not reflect the level of either ICT enabled e-government or corruption.

Despite these limitations, this paper highlights the critical need for continued research on the role of e-government in mitigating corruption, while noting that $\mathrm{e}$ - 
government has to be based on sound policies of transparency and accountability in order to be effective in targeting corruption. As Rodriguez et al. (2010) point out, future research should examine this relation with the aim of providing frameworks that focus on the efficient implementation of e-government strategies that result in a reduction in corruption.

\section{ANNEX}

The countries included in the sample are: Albania, Algeria, Angola, Argentina, Armenia, Australia, Austria, Azerbaijan, Bahrain, Bangladesh, Belarus, Belgium, Bolivia, Bosnia and Herzegovina, Botswana, Brazil, Bulgaria, Canada, Chile, China, Colombia, Congo, Croatia, Cuba, Cyprus, Czech Republic, Denmark, Dominican Republic, Ecuador, Egypt, El Salvador, Estonia, Ethiopia, Finland, France, Gambia, Germany, Greece, Guatemala, Honduras, Hungary, Iceland, India, Iran, Ireland, Israel, Jamaica, Japan, Jordan, Kazakhstan, Kenya, Kuwait, Kyrgyzstan, Latvia, Lebanon, Lithuania, Luxembourg, Macedonia, Madagascar, Malaysia, Mali, Mexico, Moldova, Morocco, Mozambique, Namibia, Netherlands, New Zealand, Nicaragua, Nigeria, Norway, Oman, Pakistan, Panama, Papua New Guinea, Peru, Philippines, Portugal, Russia, Saudi Arabia, Senegal, Sierra Leone, Singapore, Slovakia, Slovenia, South Africa, Spain, Sri Lanka, Sudan, Sweden, Switzerland, Syria, Tanzania, Thailand, Trinidad and Tobago, Tunisia, Turkey, Uganda, Ukraine, United Arab Emirates, United Kingdom, United States, Uruguay, Venezuela, Vietnam, Yemen, Zambia, and Zimbabwe

\section{REFERENCES}

AIDES, A.; DI TELLA, R. (1999), "Rents, Competition, and Corruption", American Economic Review, vol. 89, n. 4: 982-993. http://dx.doi.org/10.1257/aer. $\underline{89.4 .982}$

AIDT, T. S. (2003), "Economic Analysis of Corruption: a survey", Economics Journal, vol. 113: 632-652. http://dx.doi.org/10.1046/j.0013-0133.2003.00171.x

AHMAD, N.; BROOKINS, O. (2007), "The impact of Corruption on Efficiency in Developing Economies", International Journal of Economic Perspective, vol.1, n. 2:.64-73. http://bit.ly/V8Le9J 
ANDERSEN, T.; RAND, J. (2006), "Does E-Government reduce corruption”, University of Copenhagen, Department of Economics, Working Paper. http://bit.ly/XYNVKq

ARVIS, J. F.; BERENBEIM, R. (2004), "Fighting corruption in East Asia: Solutions from the private sector", Directions in development series - World Bank. Washington, D.C. http://bit.ly/RqunJ2

BACKUS, M., (2001), "E-Governance and Developing Countries: Introduction and example", International Institute for Communication and Development, Research Brief, March 2001. http://bit.ly/T5oSB1

BANNISTER , F; WALSH, N. (2002), “The virtual public servant: Ireland's public services broker", Information Polity: The International Journal of Government \& Democracy in the Information Age, vol. 7 no. 2/3; 115-139. http://bit.ly/SjqDux

BARATA, K.; CAIN, P. (2001), "Information, not technology, is essential to accountability: Electronic records and public-sector financial management", Information Society, vol. 17 no. 4: 247-258. http://bit.ly/X0onxq

BERTOT, J.; JAEGER, P; GRIMES, J. (2010), "Using ICT to create a culture of transparency: E-Government and social media as openness and anti-corruption tools for societies", Government Information Quarterly, vol. 27: 264-271. http://bit.ly/pZrCpq

BHARGAVA, V.; BOLONGAITA, E. (2004), "Challenging corruption in Asia: case studies and a framework for action", The International Bank for Reconstruction and Development/ The World Bank. Working Paper No. 27580. Washington, D.C. http://bit.ly/W5Urku

BRYNJOLFSSON, .E; SAUNDERS, A. (2010), Wired for innovation: How information technology is reshaping the economy, MIT press, Cambridge, Massachusetts.

CABA, C; LOPEZ, A. M.; RODRIGUEZ, M. P. (2005), “Citizen's access to online governmental financial information: Practices in the European Union Countries", Government Information Quarterly, vol. 22, n. 2: 258-276. http://dx.doi.org/10.1016/j.giq.2005.02.002

CHRISTOU, G; SIMPSON, S. (2009), "New Governance: the Internet, and 
country code Top-level Domains in Europe", Governance: an International Journal of Policy, Administration and Institutions, vol. 22, n. 4; 599-624. http://dx.doi.org/10.1111/j.1468-0491.2009.01455.x

ELliOTT, K. A. (1997), Corruption and the global economy. Institute for International Economics. Washington, D.C.

FINGER, M; PECOUD, G. (2003), "From e-Government to e-Governance? Towards a model of e-Governance", Third European Conference on $e$ Government, Trinity College, Dublin, Ireland, 3-4 July 2003. http://bit.ly/RsnJp6

GUPTA, S.; DAVOODI, H.; ALONSO-TERME, R. (1998), "Does corruption affect income inequality and poverty", International Monetary Fund. Working Paper. Washington, D. C. http://bit.ly/V8Ojq8

HAQUE, M.S. (2002), "E-governance in India: its impacts on relations among citizens, politicians and public servants", International Review of Administrative Sciences vol. 68, n. 2: 231-250. http://dx.doi.org/10.1177/0020852302682005

HOPPER, T.; TSAMENYI, M; UDDIN, S.; WICKRAMASINGHE, D. (2009), "Management accounting in less developed countries: what is known and needs knowing", Accounting, Auditing and Accountability Journal, vol. 22, n. 3, 469514. http://dx.doi.org/10.1108/09513570910945697

JAIN, A. K. (2001), “Corruption: a review”, Journal of Economic Surveys vol. 15: 72-121. http://dx.doi.org/10.1111/1467-6419.00133

KAUFMANN, D.; KRAAY, A.; ZOIDA-LOBATON, P..(2000), “ Governance Matters: from measurement to action". Finance and Development: World Bank Policy Research, vol. 37 no.2, Washington, D. C. http://bit.ly/XYS9S9

KAUFMANN, D.; KRAAY, A.; MASTRUZZI, M. (2003), "Governance Matters VIII: Aggregate and Individual Governance Indicators", World Bank Policy Research. Working Paper No. 4978. Washington, D.C. http://bit.ly/TTGxKO

KIM, C. (2007), "A cross-national analysis of global E-government", Public Organization Review, vol. 7, n. 10:.317-329. http://dx.doi.org/10.1007/s11115$\underline{007-0040-5}$

KIM, S.; KIM, H. J; LEE, H. (2009), “An institutional analysis of an e- 
Government system for anti-corruption: the case of open", Government Information Quarterly, vol. 26, n. 1:.42-50. http://bit.ly/Sv9S2f

KIMBRO, M. (2002), “A cross-country empirical investigation of corruption and its relationship to economic, cultural, and monitoring institutions: an examination of the role of accounting and financial statements quality", Journal of Accounting, Auditing, and Finance vol. 17, n.. 4:.325-349. http://dx.doi.org/10.1177/0148558 $\underline{\mathrm{X} 0201700403}$

KUDO, H. (2010), "E-Governance as strategy of public sector reform: peculiarity of Japanese IT policy and its institutional origin", Financial Accountability \& Management, vol. 26, n.1: 65-84. http://dx.doi.org/10.1111/j.1468$\underline{0408.2009 .00491 . x}$

LAN. L. (2004), "E-Government: A catalyst to good governance in China", Knowledge Management in Electronic Government vol. 3035: 317-324. http://bit.ly/Tu1KyR

LEVINE, R., 2005, Finance and Growth: Theory and Evidence, Handbook of Economic Growth, Philippe Aghion \& Steven Durlauf (ed.), Chapter 12, 865-934.

LU, M. T. (2001), "Digital divide in developing countries", Journal of Global Information Technology Management vol. 4, n. 3: 1-5. http://bit.ly/Tu1Pm4

MANSELL, R. (2001), "Digital opportunities and the missing link for developing countries", Oxford review of Economic Policy, vol.17, n. 2: 282- 295. http://dx.doi.org/10.1093/oxrep/17.2.282

MAOR, M. (2004), "Feeling the heat? Anticorruption mechanisms in comparative perspective", Governance: An International Journal of Policy, Administration and Institutions, vol.17, n. 11 1-28. http://dx.doi.org/10.1111/j.09521895.2004.00235.x

MAURO, P. (1997), “Corruption and Growth”, Quarterly Journal of Economics, vol. 110, n. 3: 681-712. http://dx.doi.org/10.2307/2946696

MIMBA, S.H.N.; VAN HELDEN J.; TILLEMA, S. (2007), "Public sector performance measurement in developing countries", Journal of Accountancy and Organizational Change, vol. 3, n..3: 192-208. http://dx.doi.org/10.1108/18325910 $\underline{710820265}$ 
MISTRY, J.J. (2005), "A conceptual framework for the role of government in bridging the digital divide". Journal of Global Information Technology Management vol. 8, n 3: 28-46. http://bit.ly/Tu6rIV

MISTRY, J.J. (2012), “The Role of eGovernance in mitigating corruption", .Accounting and the Public Interest, vol. 12, n. 1: 137-159. http://bit.ly/Yn2giX

PALVIA, S.; SHARMA, S. (2007), "E-Government and e-Governance: Definitions/Domains, Framework and status around the world", International Conference on e-Government, 2007; 1-15. http://ww.csi-sigegov.org/1/1_369.pdf.

RODRIGUEZ BOLIVAR, M. P.; MUNOZ, L. A.; LOPEZ, A. M. (2010), "Trends of e-Government research, contextualization and research opportunities", The International Journal of Digital Accounting Research, vol. 10, n. 1: 87-111. http://www.uhu.es/ijdar/10.4192/1577-8517-v10_4

RODRIGUEZ-DOMINGUEZ, L.; SANCHEZ, I. M. G.; ALVAREZ, I. G. (2011), "From emerging to connected e-Government: the effects of socioeconomics and internal administration characteristics", The International Journal of Digital Accounting Research, vol. 11, n. 1: 85-109. http://bit.ly/TTJjzE

ROJKO, K.; LESJAK, D.; VEHOVAR, V. (2011), "Information communication technology spending in (2008-) economic crisis", Industrial Management and Data Systems, vol. 111, n. 3: 391-409. http://bit.ly/Tu22px

ROSE-ACKERMAN. S. (1999), Corruption and government: causes, consequences and reform, Cambridge University Press, Cambridge.

SIAU, K.; LONG, Y. (2006), "Using social development lenses to understand eGovernment development”, Journal of Global Information Management, vol. 14, n. 1: 47-62. http://dx.doi.org/10.4018/jgim.2006010103

SINGH, G., R.; PATHAK, R.; NAZ, R; Belwal R. (2010), "E-governance for improved public sector service delivery in India, Ethiopia and Fiji”, International Journal of Public Sector Management, vol. 23, n. 3: 254-275. http://dx.doi.org/ $\underline{10.1108 / 09513551011032473}$

SHIM, D. C.; EOM. T. H. (2008), "E-Government and anti-corruption: empirical analysis of international data", International Journal of Public Administration, vol. 31, n. 3: 298-316. http://dx.doi.org/10.1080/01900690701590553 
SHIM, D. C.; EOM. T. H. (2009), "Anti-corruption effects of information communication technology (ICT) and social capital", International Review of Administrative Sciences, vol. 75, n. 1: 99-116. http://dx.doi.org/10.1177/00208523 $\underline{08099508}$

SVENSSON, J. (2005), "Eight questions about corruption”, Journal of Economic Perspectives vol. 19, n. 3:.19-42. http://dx.doi.org/10.1257/089533005774357860

TANZI, V. (1998), "Corruption around the world: causes, consequences, scope and cures", International Monetary Fund. Working Paper 98/63. Washington, D.C. http://bit.ly/5BIhBw

TANZI, V.; DAVOODI, H. (1997), "Corruption, public investment and growth", International Monetary Fund. Working Paper 97/139. Washington, D.C. http://bit.ly/PGNT9q

TORRES, L.; PINA, V.; ACERATE, B. (2006), "E-governance developments in European Union cities: reshaping government's relationship with citizens", Governance: An International Journal of Policy, Administration, and Institutions. vol. 19, n. 2: 277-302. http://dx.doi.org/10.1111/j.1468-0491.2006.00315.x

VASARHELYI, M.; ALLES, M. G. (2008), "The "now" economy and the traditional accounting reporting model: Opportunities and challenges for AIS research", International Journal of Accounting Information Systems. vol. 9, n. 4: 227-239. http://dx.doi.org/10.1016/j.accinf.2008.09.002

VITTAL, N. (2003). Corruption in India. Academic Foundation, New Delhi, India.

WEST, D. (2004), "E-government and the transformation of service delivery and citizen attitudes", Public Administration Review. vol. 64, n. 1: 15-27. http://dx.doi.org/10.1111/j.1540-6210.2004.00343.x

ZHANG, J.; ZHANG, Z. (2009) “Applying E-government information system for anti-corruption strategy", Proceedings of the 2009 International conference on management of e-Commerce and e-Government: 112-115. http://dx.doi.org/10.11 09/ICMeCG.2009.40 